\title{
Archaeological Testing of Site 41WL19 Waller County, Texas
}

Glenn T. Goode

Follow this and additional works at: https://scholarworks.sfasu.edu/ita

Part of the American Material Culture Commons, Archaeological Anthropology Commons, Environmental Studies Commons, Other American Studies Commons, Other Arts and Humanities Commons, Other History of Art, Architecture, and Archaeology Commons, and the United States History Commons

Tell us how this article helped you.

This Article is brought to you for free and open access by the Center for Regional Heritage Research at SFA ScholarWorks. It has been accepted for inclusion in Index of Texas Archaeology: Open Access Gray Literature from the Lone Star State by an authorized editor of SFA ScholarWorks. For more information, please contact cdsscholarworks@sfasu.edu. 


\section{Archaeological Testing of Site 41WL19 Waller County, Texas}

\section{Licensing Statement}

This is a work produced for the Texas Department of Transportation (TxDOT) by the report producer. TxDOT and the report producer jointly own all rights, title, and interest in and to all intellectual property developed under TXDOT's contract with the report producer. The report may be cited and brief passages from this publication may be reproduced without permission provided that credit is given to both TxDOT and the report producer. Permission to reprint an entire chapter, section, figures or tables must be obtained in advance from either the Supervisor of the Archeological Studies Branch, Environmental Affairs Division, Texas Department of Transportation, 125 East 11th Street, Austin, Texas, 78701 or from the report producer. 
ARCHAEOLOGICAL TESTING OF SITE 41 WL19

WALLER COUNTY, TEXAS

By

Glenn T. Goode

Texas

State Department of Highways and Public Transportation Highway Design Division

September 1984 


\begin{abstract}
Testing of Site 4 WL19 on State Highway 6 in Waller County, to determine elibigility for inclusion within the National Register of Historic Places and to determine site depth, cultural context, and archaeological significance, was undertaken in July 1984. The site lies on a sandy hilltop above Donahoe Creek, directly across State Highway 6 from St. Luke's Church in the community of Cedar Creek, and is evidenced by sparse lithic debris. Evidence recovered demonstrates that insufficient material is present within the proposed right-of-way to support a determination of eligibility for inclusion within the National Register of Historic Places.
\end{abstract}




\section{INTRODUCTION}

Archaeological Site 41WL19 was recorded at the Texas Archeological Research Laboratory of the Balcones Research Center, The University of Texas at Austin, in April 1984, by a member of the State Department of Highways and Public Transportation (SDHPT) professional cultural resources staff. Following initial evaluation, further investigation and testing were recommended. During the period of July 11 to July 17, 1984, testing operations were conducted by Glenn T. Goode of the SDHPT professional cultural resources staff with field support personnel provided by the SDHPT District 12 office. Testing was performed under the auspices of Procedures for the Protection of Historic and Cultural

Properties (36 CFR, Part 800), procedures prescribed and endorsed by the Federal Highway Administration. The object of the test was to determine eligibility for inclusion of the site within the National Register of Historic Places as prescribed by federal regulation and to determine the nature of the deposits and the cultural context of the site.

The highway construction project affecting the site consists of the construction of a new two-lane roadway to complement the existing facility. State Highway 6 is a four-lane facility from Houston to US 290 in Hempstead. State Highway 6 is also a four-lane facility in Grimes County; therefore, the section of State Highway 6 between US 290 and the Grimes County line will be the final link in State Highway 6 .

The facility is planned to be four 12-ft. lanes divided by a 76-ft. median. The existing facility will be incorporated into the design to allow for one direction of travel, with an additional two-lane facility to be constructed. Two bridge structures will also be required, one at Donahoe Creek and one at Cedar Creek.

The site, 41WL19, is located on a sandy hilltop to the north of Donahoe Creek, directly across existing State Highway 6 from St. Luke's Church 
in the small community of Cedar Creek (Fig. 1). The area, a part of the East Texas Timberlands region, is characterized by low, slightly rolling terrain. Vegetation consists of hardwoods such as oak, elm, hickory, and magnolia. Forage plants for cattle include bluestem, panicum, paspalum, and Indian grass. The immediate area consists of improved pasture. Portions of the site have been affected by the initial construction of existing State Highway 6, which passes through the site area.

Surface evidence of cultural materials consisted of a sparse lithic scatter, comprised of small flakes. No evidence of cultural materials other than small flakes was noted on the surface. The site appeared to extend some $250 \mathrm{ft}$. along State Highway 6, and was present on both sides of the existing highway.

The soils consist of sandy and loamy savannah soils of the TaborTremona-Chazos association. In the site area the soils belong to the Axtell Series which are soils characterized as deep, moderately well drained, loamy soils on ancient stream terraces, formed in loamy and clayey alluvium. Slopes range from 1 to 8 percent. When dry, the soil can have cracks that are $1 / 2 \mathrm{in}$. wide a t a depth of $20 \mathrm{in}$. (Greenwade 1984). 
This Page Redacted Per THC Policy 
PROCEDURES

Archaeological testing of Site 4 WL19 consisted of surface observation and test units excavated by hand (Fig. 2). Five test units were excavated in controlled vertical increments, and one shovel test was made. Test units were excavated in $10 \mathrm{~cm}$ levels and consisted of one 1 by 1 meter unit, three 1 by 2 meter units, and one 2 by 2 meter unit which was reduced to a 1 by 2 meter unit after two levels. The location of all test units was established with the centerline of the proposed facility as a reference. All matrix was passed through 0.25 in. hardware cloth screens, and recovered material was removed from the site for analysis and temporary storage at the SDHPT Laboratory for Archaeological Studies. 


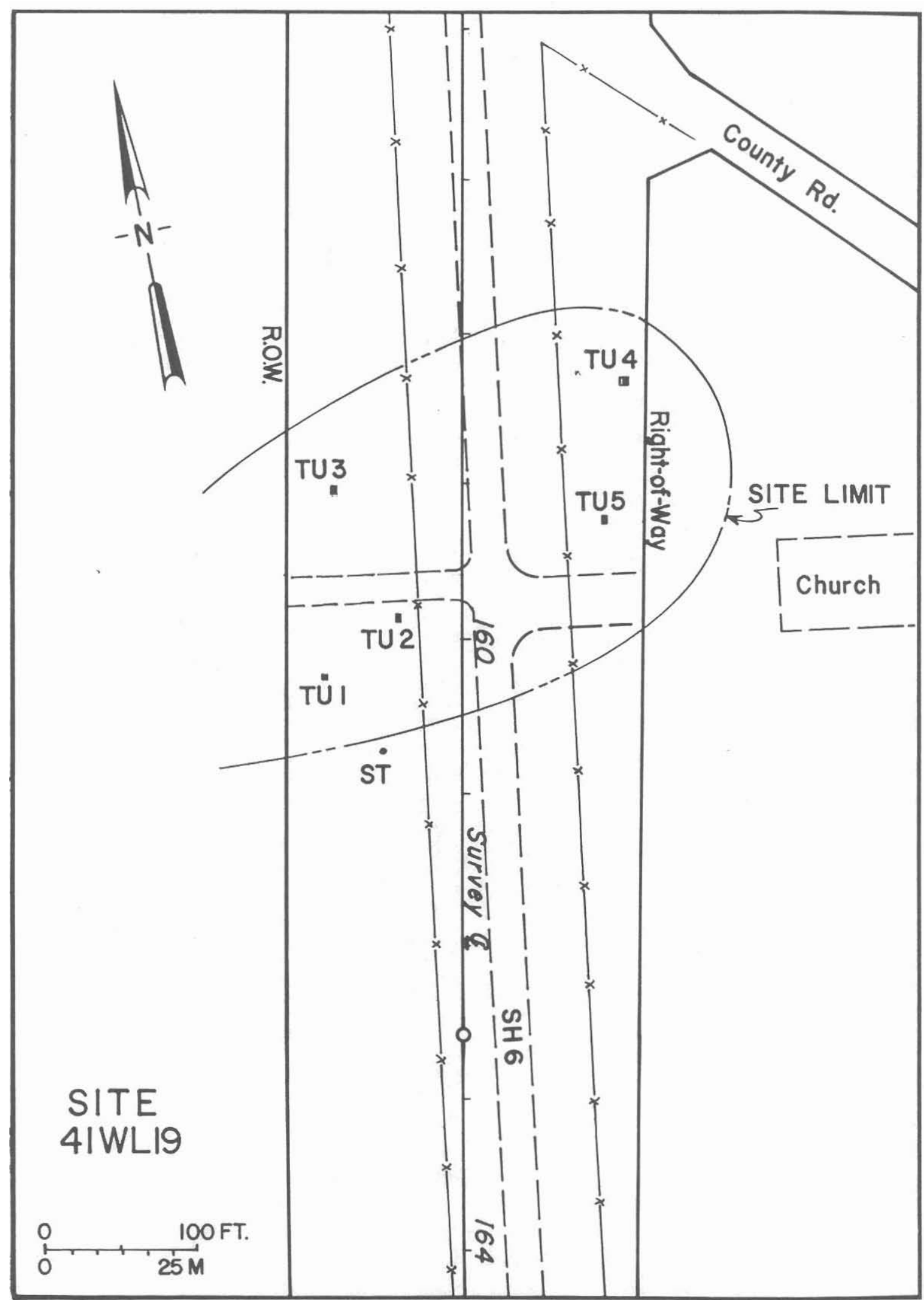

FIGURE 2. Project area showing limit of Site 41WL19 and location of test units. 
A total of 178 flakes was recovered from the five test units. Little meaningful vertical variation was observed. Of this sample, 151 flakes were recovered from Test Unit 2. These were evenly distributed throughout the fifteen levels of this test unit. The remaining test units were relatively nonproductive, with Test Unit 1 producing 10 flakes, Test Unit 3 producing 4 flakes, Test Unit 4 producing 7 flakes, and Test Unit 5 producing 6 flakes. All material recovered came from the loamy sand which is underlain by a sterile compact sandy clay. No diagnostic artifacts were recovered from the site and no features were observed. No historic material was encountered. 
CONCLUSIONS AND RECOMMENDATIONS

The artifact sample from Site 4 WL19 consists of 178 small flakes. Of these, 4 specimens are quartzite, 3 are petrified wood, and 171 are chert. All of this material could be of local origin, possibly from Brazos River gravel deposits. Ten flakes are 30 to $40 \mathrm{~cm}$ in length. Most are much smaller, being less than $20 \mathrm{~mm}$ in length.

A brief analysis of 151 flakes indicates that approximately 49\% have attributes of soft-hammer reduction, 19\% of hard-hammer, and 32\% are fragments. Due to the small size of the specimens recovered and the overlap in platform characteristics, these figures are not particularly meaningful. Some 51\% of the flakes have secondary cortex, most with only a small amount present. Some 49\% are of interior origin. There were no primary flakes in the sample. Thermally altered stone recovered consists of 5 burned chert flakes and one potlid.

This assemblage of small flake debitage represents intermediate and possibly final stage reduction of relatively small raw material. No modification was observed on any specimen, and therefore none are classified as tools. No bifaces, unifaces, or ground stone tools were found and no features were identified. One small core fragment was found on the surface.

The lithic assemblage indicates that Site 41WL19 possibly served as a minor campsite whose only discernible activity was the limited reduction of small chert cobbles. On the basis of the material recovered from the testing operations, it is believed that the portion of the site lying within the proposed right-of-way does not meet the criteria for inclusion within the National Register of Historic Places. The site exhibits a general paucity of cultural material, a lack of adequate stratification, and an apparent lack of features--factors which suggest that it does not contain significant information worthy of further study. In view of these considerations, no further investigation of Site 41WL19 is recommended. 


\section{REFERENCES CITED}

Greenwade, James M.

1984 Soil Survey of Austin and WallerCounties, Texas. United States Department of Agriculture, Soil Conservation Service. 